\title{
NOTES ON TWO CASES OF TRANSPORT AND SURVIVAL OF TERRESTRIAL MOLLUSCA IN THE NEW FOREST.
}

By T. Leighton, F.G.S., etc.

Read April 19th, 1895.

It would be interesting to know whether Helix rupestris, Drap., and Pupa umbilicata, Drap., occur at large in the New Forest. In 1888 I was able to collect a number of specimens of these two species from an old limestone tomb in Brockenhurst churchyard. The neighbouring walls of the church and other memorials in the churchyard were carefully examined without yielding any result. The subsoil of the New Forest consists almost entirely of gravel and sand, so that it is not a locality in which one would expect to find many snails. I have searched the beeches in vain for Clausilia in different parts of the forest; in fact, the only snail above suspicion which I have obtained in the district is a single specimen of Vitrea nitida, Müll., which occurred in the northern lane leading from the village of Brockenhurst to the church. It is suggested that the two species first mentioned were probably introduced with the tombstone on which they still probably occur (they were there in July, 1894). In the brickyard at Roydon, near Brockenhurst, Helix caperata, Mont., and H. virgata, Da Costa, occur over the waste-heaps of the Headon shell-beds, which are, of course, strongly calcareous. The snails appear to be strictly confined to these waste-heaps, however; they cannot be found in the neighbouring hedgerows, and the beeches, even in the brickyard, are without Clausilia, so far as I could see. Here, again, the snails have probably been introduced, either on the workmen's tools or with brick-making plant. 


\section{$2 \mathrm{BHL}$ Biodiversity Heritage Library}

1895. "NOTES ON TWO CASES OF TRANSPORT AND SURVIVAL OF TERRESTRIAL MOLLUSCA IN THE NEW FOREST." Proceedings of the Malacological Society of London 1, 296-296.

View This Item Online: https://www.biodiversitylibrary.org/item/52295

Permalink: https://www.biodiversitylibrary.org/partpdf/202612

\section{Holding Institution}

Smithsonian Libraries

\section{Sponsored by}

Smithsonian

\section{Copyright \& Reuse}

Copyright Status: Public domain. The BHL considers that this work is no longer under copyright protection.

This document was created from content at the Biodiversity Heritage Library, the world's largest open access digital library for biodiversity literature and archives. Visit BHL at https://www.biodiversitylibrary.org. 